\title{
Seed Bio Priming for Enhancing Growth and Yield Attributes in Finger Millet Varieties (Eleusine coracana L. Garten.)
}

\author{
Soumya $^{1 *}$, S.M. Prashant ${ }^{1}$, Sangeeta I. Macha ${ }^{1}$, Vijay Kumar Kurnalliker ${ }^{1}$, \\ L.N. Yogeesh ${ }^{2}$ and A. Ravikumar ${ }^{3}$
}

${ }^{1}$ Department of Seed Science and Technology, ${ }^{2}$ Department of Genetics and Plant Breeding,

${ }^{3}$ Department of Sericulture, College of Agriculture, Raichur, University of Agricultural Sciences, Raichur- 584 104, India

*Corresponding author

\section{Keywords}

Priming, Yield,

Finger millet,

Trichoderma

Article Info

Accepted:

12 December 2020

Available Online:

10 January 2021
Seeds were bio primed with Hydropriming, biopriming with Azospirillum brasilense@20\%,Pseudomonas fluorescens@20\%, Phosphobacteria @20\%,Trichoderma harzianum @1\%,beejamrutha@50\%,vermiwash @2\%, cow urine @ 25\% and waste decomposer@20\% for two varieties GPU-67 and HR-13. The growth parameters differed significantly between the treatments. Seed bio primed with Trichoderma harzianum @ $1 \%$ along with HR-13 recorded highest plant height $(90.00 \mathrm{~cm})$ and number of tillers per plant (6.76) at harvest, respectively. The yield parameters differed significantly between the treatments. Seed bio primed with Trichoderma harzianum @ $1 \%$ along with HR-13 recorded highest finger length (8.10 $\mathrm{cm})$, number of fingers per head (8.16), ear head weight $(27.82 \mathrm{~g})$, test weight $(6.30 \mathrm{~g})$, seed yield per hectare $(2896.00 \mathrm{~kg} / \mathrm{ha})$ and fodder yield per hectare $(9888.88 \mathrm{~kg} / \mathrm{ha})$.

\section{Introduction}

Finger millet (Elusine coracana L. Garten.) commonly called as ragi in India. The generic name Eleusine is derived from the Greek goddess of cereals, "Eleusine" while the common name finger millet indicates "fingerlike" branching of the panicle. It is native to Ehiopian highlands. Finger millet is an important staple food in the Eastern and
Central Africa as well as some parts of India as such, it may be one of the oldest indigenous domesticated tropical cereals in Africa. It ranks third in importance among millets in the country. It has dual importance as a source of food grain as well as straw. Straw is excellent as animal fodder with up to a total of 60 per cent digestible nutrients and is grown in an area of 1016 thousand hectare with an annual production of 1385 thousand 
tones and with productivity of $1363 \mathrm{~kg}$ per ha (Anon., 2017).

It is a highly productive crop that can thrive under a variety of harsh environmental conditions, and is also organic by default. It can be grown on low fertility soils and is not dependent on the use of chemical fertilizers, hence, is a boon for the vast arid and semiarid regions (Gull et al., 2014). It is also known to be one of the most efficient utilizer of nitrogen (Gupta et al., 2014). Finger millet seeds can resist storage pests, ensuring round the year food supply or even during a crop failure, that has earned it the popular name of 'famine crop' (Mgonja et al., 2007). Ragi is considered to be an ideal food for diabetic individuals due to its low sugar content and slow release of glucose/sugar in the body its nutritional significance in providing minerals, calories and protein makes it an ideal model for nutrition.

The seed bio priming is an effective seed treatment to increase the rate, uniformity of emergence and crop establishment in most of the crops especially in advanced countries in last two decades. It integrates the biological and physiological aspects of enhancing growth, disease control and increase yield, which involves coating of seeds with biological agents and incubating the seeds under warm, moist conditions. Excessive and continues use of chemical fertilizers coupled with fungicide have damaged the production and productivity of different crops. Hence, present study was under taken to identify the best bio priming for finger millet crop.

\section{Materials and Methods}

A field experiment was conducted to study the effect of seed bio priming on growth and yield parameters in finger millet (Eleusine coracana L. Garten.) varieties during kharif 2019 at Agricultural Research Station, Hagari.
The experiment was carried out in factorial completely randomized design (FRCBD). There were thirty six plots comprising of two varieties [GPU-67 and HR-13], nine treatments $\left(\mathrm{T}_{\mathrm{o}}-\right.$ Hydro priming, $\mathrm{T}_{1}$ Azospirillum brasilense @ $20 \%, \mathrm{~T}_{2}$ Phosphobacteria@20\%, $\mathrm{T}_{3}$-Pseudomonas fluorescens @20\%, $\mathrm{T}_{4}$ - Trichoderma harzianum@1\%, T5-Beejamrutha@50\%, $\mathrm{T}_{6}$-Cow urine@25\%, T - Vermiwash@2 $\%, \mathrm{~T}_{8}$ - Waste decomposer @ $20 \%$ ) and interaction between varieties and varieties and treatments.

\section{Results and Discussion}

Growth parameters differed significantly due to different seed bio priming treatments. The finger millet seeds bio primed with Trichoderma harzianum @ 1 \% recorded highest plant height $(87.00 \mathrm{~cm})$ and number of tillers per plant (6.45) at harvest, respectively. While in seeds bio primed with waste decomposer @ $20 \%$ recorded lowest plant height $(78.03 \mathrm{~cm})$ and number of tillers per plant (4.90) at harvest.

Growth parameters were differed significantly in both the varieties. The variety HR-13 recorded highest plant height $(83.07 \mathrm{~cm})$ and number of tillers per plant (5.94) at harvest, respectively. While, in variety GPU-67 recorded lowest plant height $(80.46 \mathrm{~cm})$ and number of tillers per plant (5.30) at harvest. Interactions between varieties and seed bio priming treatments differed significantly for growth parameters. Highest plant height $(90.00 \mathrm{~cm})$ and number of tillers per plant (6.76) at harvest was recorded in treatment Trichoderma harzianum @ $1 \%$ in variety HR-13. while, lowest plant height at harvest was noticed in treatment waste decomposer @ $20 \%$ in variety HR-13 $(78.00 \mathrm{~cm})$. Lowest number of tillers per plant (4.73) at harvest, respectively was recorded in treatment waste decomposer@20\% in variety GPU-67. 
Table.1 Influence of seed biopriming on plant height at harvest $(\mathrm{cm})$, number of tillers per plant at harvest, number of fingers per head, finger length $(\mathrm{cm})$ in finger millet varieties $c v$. GPU-67 and HR-13

\begin{tabular}{|c|c|c|c|c|c|c|c|c|c|c|c|c|}
\hline \multirow[t]{2}{*}{ Treatments } & \multicolumn{3}{|c|}{ Plant height at harvest } & \multicolumn{3}{|c|}{$\begin{array}{c}\text { Number of tillers per } \\
\text { plant at harvest }\end{array}$} & \multicolumn{3}{|c|}{ Number of fingers per head } & \multicolumn{3}{|c|}{ Finger length } \\
\hline & $\begin{array}{c}\text { GPU- } \\
67\end{array}$ & HR-13 & MEAN & GPU-67 & HR-13 & $\begin{array}{l}\text { ME } \\
\text { AN }\end{array}$ & $\begin{array}{c}\text { GPU- } \\
67\end{array}$ & HR-13 & MEAN & GPU-67 & HR-13 & MEAN \\
\hline $\mathbf{T}_{0}$-Hydro priming & 79.00 & 81.00 & 80.00 & 5.21 & 6.13 & 5.67 & 7.04 & 7.07 & 7.06 & 7.15 & 7.36 & 7.26 \\
\hline $\begin{array}{l}\mathrm{T}_{1} \text {-Azospirillum } \\
\text { brasilense@20\% }\end{array}$ & 79.80 & 85.66 & 82.73 & 5.43 & 6.33 & 5.88 & 7.06 & 7.14 & 7.10 & 7.19 & 7.50 & 7.34 \\
\hline $\begin{array}{l}\mathbf{T}_{2-P h o s p h o b a c t e r i a @} @ \\
20 \%\end{array}$ & 80.93 & 88.00 & 84.46 & 5.64 & 6.40 & 6.02 & 7.25 & 7.66 & 7.46 & 7.33 & 7.73 & 7.53 \\
\hline $\begin{array}{l}\mathrm{T}_{3} \text {-Pseudomonas } \\
\text { fluorescens @ } 20 \%\end{array}$ & 83.26 & 89.00 & 86.13 & 5.81 & 6.63 & 6.22 & 7.16 & 7.96 & 7.56 & 7.36 & 7.89 & 7.62 \\
\hline $\begin{array}{l}T_{4}-\text { Trichoderma } \\
\text { harzianum@1\% }\end{array}$ & 84.00 & 90.00 & 87.00 & 6.13 & 6.76 & 6.45 & 7.56 & 8.16 & 7.86 & 7.68 & 8.10 & 7.89 \\
\hline $\begin{array}{l}\mathbf{T}_{5} \text {-Beejamrutha @ } \\
50 \%\end{array}$ & 80.30 & 78.83 & 79.56 & 5.2 & 5.70 & 5.45 & 7.04 & 7.09 & 7.06 & 7.00 & 7.23 & 7.11 \\
\hline $\mathbf{T}_{6}$-Cow urine @ 25\% & 79.30 & 77.90 & 78.60 & 4.81 & 5.30 & 5.05 & 7.02 & 7.06 & 7.04 & 7.08 & 7.10 & 7.09 \\
\hline $\mathbf{T}_{7}$-Vermiwash@ @ \% & 79.50 & 79.26 & 79.38 & 4.74 & 5.20 & 4.97 & 7.36 & 7.01 & 7.19 & 7.16 & 6.94 & 7.04 \\
\hline $\begin{array}{l}T_{8} \text {-Waste decomposer } \\
\text { @ } 20 \%\end{array}$ & 78.06 & 78.00 & 78.03 & 4.73 & 5.06 & 4.90 & 7.00 & 6.90 & 6.95 & 7.11 & 6.93 & 7.02 \\
\hline \multirow[t]{2}{*}{ MEAN } & 80.46 & 83.07 & & 5.30 & 5.94 & & 7.17 & 7.34 & & 7.23 & 7.42 & \\
\hline & S.Em \pm & $\begin{array}{c}\mathrm{CD} @ \\
5 \%\end{array}$ & & S.Em \pm & $\begin{array}{c}\mathrm{CD} @ \\
5 \%\end{array}$ & & $\begin{array}{l}\text { S.Em } \\
\pm\end{array}$ & $\begin{array}{c}\mathrm{CD} @ \\
5 \%\end{array}$ & & S.Em \pm & $\begin{array}{c}\mathrm{CD} @ \\
5 \%\end{array}$ & \\
\hline V & 0.126 & 0.362 & & 0.014 & 0.042 & & 0.040 & 0.115 & & 0.017 & 0.051 & \\
\hline $\mathbf{T}$ & 0.271 & 0.771 & & 0.030 & 0.089 & & 0.090 & 0.245 & & 0.042 & 0.109 & \\
\hline $\mathbf{V} \times \mathbf{T}$ & 0.379 & 1.090 & & 0.044 & 0.127 & & 0.121 & 0.346 & & 0.053 & 0.155 & \\
\hline
\end{tabular}


Table.2 Influence of seed biopriming on ear head weight (g), test weight (g), seed yield per hectare (kg/ha), fodder yield per hectare $(\mathrm{kg} / \mathrm{ha})$ in finger millet varieties $c v$. GPU-67 and HR-13

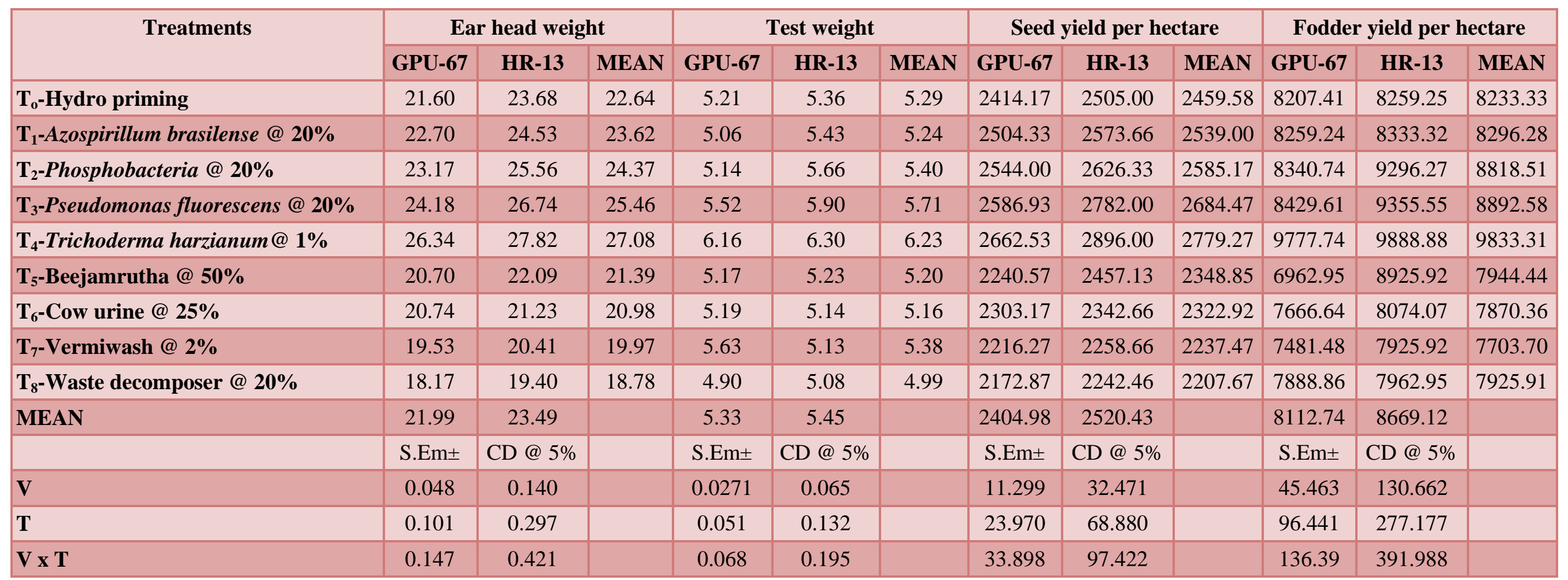


Yield parameters differed significantly due to different seed biopriming treatments. Finger millet seeds bio primed with Trichoderma harzianum@1\% recorded highest finger length $(7.89 \mathrm{~cm})$, number of fingers per head (7.86), ear head weight ( $27.08 \mathrm{~g})$, test weight $(6.23 \mathrm{~g})$, seed yield per hectare $(2779.27 \mathrm{~kg})$ and fodder yield per hectare $(9833.31 \mathrm{~kg})$. While, the lowest was recorded in seeds bio primed with waste decomposer @ $20 \%$ (7.02 cm 6.95, $18.78 \mathrm{~g}, 4.99 \mathrm{~g}, 2207 \mathrm{~kg}$ and 7925 $\mathrm{kg}$, respectively). All the yield parameters differed significantly in both the varieties. The variety HR-13 recorded highest number of fingers per head (7.34), finger length (7.42 $\mathrm{cm})$, ear head weight $(23.49 \mathrm{~g})$, test weight $(5.45 \mathrm{~g})$, seed yield per hectare $(2520.43 \mathrm{~kg})$ and fodder yield per hectare $(8669.12 \mathrm{~kg})$. While, the lowest was recorded in variety GPU-67 (7.17, $7.23 \mathrm{~cm}, 21.99 \mathrm{~g}, 5.33 \mathrm{~g}$, $2404.98 \mathrm{~kg}$ and $8112.74 \mathrm{~kg}$, respectively).

Interactions between varieties and different seed bio priming treatments differed significantly in yield parameters. Seeds bio primed with Trichoderma harzianum @1\% coupled with variety HR-13 recorded highest finger length $(8.10 \mathrm{~cm})$, number of fingers per head (8.16), ear head weight (27.82 g), test weight $(6.30 \mathrm{gm})$, seed yield per hectare $(2896.00 \mathrm{~kg})$ and fodder yield per hectare $(9888 \mathrm{~kg})$. While, the lowest ear head weight $(18.17 \mathrm{~g})$, test weight (4.90 g) and seed yield per hectare $(2172.87 \mathrm{~kg})$ was recorded in treatment waste decomposer @ $20 \%$ coupled with variety GPU-67 and lowest finger length $(6.93 \mathrm{~cm})$ was noticed in treatment waste decomposer @ $20 \%$ with variety HR-13. While, lowest fodder yield $(6962.95 \mathrm{~kg})$ was noticed in treatment beejamrutha @ 50\% with variety GPU-67.

The present study revealed that significant differences in plant height at all the growth stages of crops under study were due to biopriming and similar results were given by
Janardan Yadav et al., (2010) in cowpea who concluded that the increase in plant height might be due to the early emergence of the bio-primed seeds which makes the plant to compete well with the weeds and higher rate of accumulation of dry matter due to atmospheric nitrogen fixation and phosphorous solubilization. Priya et al., (2018) seedling bio-priming with $T$. harzianum positively influences the growth promotion, nutrient uptake and nutrient use efficiency in rice plant under different soil conditions. Abdullahi et al., (2014) reported significant difference for number of tillers per plant in pearl millet and Gangwar and Sinha (2014) in rice.

The increased rate of emergence could be correlated with early flowering and early maturity observed in the present study. Similar observations in advancement of flowering were also stated by Niranjan et al., (2004) in pearl millet. Harris et al., (1999) conducted a on farm trail in eastern India reported that primed seeds flowered earlier and matured earlier than control. Arif (2005) indicated that plants of primed seeds reached earlier at flowering and maturity as compared to plants of nonprime seeds in soyabean. The present findings confirm the results of Zarei et al., (2011) in chickpea, Similar significant findings for days to 50 per cent flowering have earlier reported by Anitha et al., (2015) in soyabean.

The increase in the number of fingers per head and finger length may be due to the synthesis of better carbohydrates transformation which resulted in better growth and length of panicle which ultimately results in increasing the yield. Same trend was also seen by Niranjan Raj et al., (2004) in finger millet. (Patra and Haque, 2011) reported that productive tillers are very important because the final yield is mainly a function of the number of panicles bearing 
tillers per unit area. Similar results were reported by (Rawat et al., 2018) in barnyard millet.

Test weight is increased in Trichoderma treatment in our study which directly affects the seed yield and quality of seed lot. The response of bio priming on seed weight has been reported by Niranjan Raj et al., (2004) in pearl millet. Similar results were previously reported by (Mishra et al., 2014).

The increase in grain yield might be due to positive influence of bio-agent in initiation and growth of roots that in turn speed up and increased the uptake of essential elements and moisture from the soil. Similar results were also reported by (Kumar, 2013) and (Rawat et al., 2018) in barnyard millet. Species of Trichoderma are considered as potent antagonists due to ability of production of antibiotics and cell wall degrading enzymes, competition for key nutrients, parasitism and stimulation of plant defense mechanism (Ushamalini et al., 2008) in turmeric plant. Reddy et al., (2011) indicated that seed priming with $T$. viridae improved seed yield and quality of chickpea due to their growth promoting and biocontol activities. This findings is in close conformity with the findings of (Hassan, 2014) also reported higher biological yield in wheat. (Rawat et al., 2018), Khatso and Tiameren (2013) and Samanhudi (2014) has previously mentioned the maximum biological yield per plant in barnyard millet.

Increase in fodder yield in our experiment was due to fact that Trichoderma When inoculated with crop seeds they suppress the growth of many soil borne plant pathogenic microorganisms which help to alleviate stress, reduce incidence of plant diseases, promote good crop stand and qualitative yields. The results are in close agreement with Meena et al., (2013) who observed the increased rice straw yield for priming as compared to no soaking. Islam (2009) in rice stated the same results that Trichoderma increased grain and straw yield.

\section{References}

Abdullahi, R., Sheriff, H. H. and Buba, A. 2014, Effect of bio-fertilizer and organic manure on growth and nutrients content of pearl millet. J. Agric. Biol. Sci., 9: 351- 355.

Anitha, Mummigatti, U. V. and Jahagirdar, S. 2015, Influence of seed bio priming agents on yield, yield parameters and purple seed stain disease in soyabean. Karanataka J. Agric. Sci., 28: 20-23.

Arif, M. 2005, Effect of seeds priming on emergence, yield and storability of soyabean. Ph.D. Thesis, NWFP Univ. Peshawar. 190-195.

Anonymous. 2017, www.indiastat.com.

Gangwar, G. P. and Sinha, A. P. 2014, Effect of fungal and bacterial bio-agent application on total phenolic content in rice leaves pre-inoculated with Xanthomonas oryzae pv. Oryzae. J. Appl. Nat. Sci., 6: 254-257.

Gull, A., Jan, R., Nayik, G. A., Prasad, K. and Kumar, P. 2014, Significance of finger millet in nutrition, health and value added products: a review. J. Environ. Sci. Com. Sci. Eng. Tech., 3: 16011608.

Gupta, S., Gupta, S. M., Gupta, A. K., Gaur, V. S. and Kumar, A. 2014, Fluctuation of Dof1/Dof2 expression ratio under the influence of varying nitrogen and light conditions: Involvement in differential regulation of nitrogen metabolism in two genotypes of finger millet (Eleusine coracana L.). Genetics. 546: 327-335.

Hasssan, M. D. M. 2014, Effect of Trichoderma and fungicide on seedling establishment and yield performance of dry direct seeded rice. Thesis, M.Sc. 
(Agri) Agronomy, Bangladesh Agricultural University, 63.

Harris, D., Joshi, P. A., Khan, P., Gothkar, P. and Sodhi, S. 1999, On-Farm seed priming in semi arid agriculture. Development and evolution in maize, rice and chickpea in India using participatory methods. Exp. Agric., 35: 15-29.

Islam, S. 2009, Comparative efficacy of BAU- Biofungicide and Tilt in controlling diseases of rice: An M.Sc. (Agri) Thesis submitted to the Dept. of Plant Pathology, Bangladesh Agricultural University, Mymensingh.

Janardan Yadav., Jay Prakash Verma. and Kavindra Nath Tiwari. 2010, Effect of plant growth promoting Rhizobacteria on seed germination and plant growth Chickpea (Cicer arietinum L.) under in vitro conditions. Int. J. Biol. Forum. 2: $15-18$.

Khatso, K. and Tiameren. 2013, Biocontrol of rhizome rot disease of ginger (Zingiber officinale Rosc.). Int. J. Bio-resource stress Manage., 4: 317-321.

Kumar, B. 2013, Management of grain smut disease of barnyard millet (Echinochola frumentaceae). Indian Phytopathol., 66: 403-405.

Meena, V. S., Maurya, B. R., Verma, R., Meena, R., Meena, R. S., Jatav, G. K. and Singh, D. K. 2013, Influence of growth and yield attributes of wheat (Triticum aestivum L.) by organic and inorganic sources of nutrients with residual effect under different fertility levels. The Bioscan, 8: 811-815.

Mgonja, M. A., Lenne, J. M., Manyasa, E. and Sreenivasaprasad, S. 2007, Finger millet blast management in East Africa. Creating opportunities for improving production and utilization of finger millet, in Proceedings of the First International Finger Millet Stakeholder Workshop, Projects R8030 \& R8445
UK Department for International Development-Crop Protection Programme. 196.

Mishra, G., Kumar, N., Giri, K., Pandey, S. and Kumar, R. 2014, Effect of fungicides and bio-agents on number of microorganisms in soil and yield of soybean (Glycine max). Nusa. Biosci., 6: 45-48.

Niranjan Raj, S., Shetty, N. P. and Shetty, H. S. 2004, Seed bio-priming with Pseudomonas fluorescens isolates enhances growth of pearl millet plants and induces resistance against downy mildew. Int. J. Pest Manage., 50: 41-48.

Patra, P. S. and Haque, S. 2011, Effect of seedling age on tillering pattern and yield of rice (Oryza sativa L.) under system of rice intensification. J. Agric. Biol. Sci. 6: 33-35.

Priya, P., Bisen, K., Rakshit, A. and Singh, H. B. 2018, Seedling Bio-priming with Trichoderma spp. enhances nitrogen use efficiency in Rice. In Advances in Seed Priming. 297-307.

Rawat, L., Tiwari, A., Bisht, T. S., Prasad, S. and Yadav. V. 2018, Effect of biopriming and colonized FYM with biocontrol agents on quantitative and qualitative traits and disease management in barnyard millet (Echinochloa crusgalli L.). Int. J. Agric. Sci., 14: 335-343.

Reddy, A. S. R., Madhavi, G. B., Reddy, K. G. and Yellareddygari, S. K. 2011, Effect of seed bio priming with Trichoderma viride and Pseudomonas fluroscence in chickpea in Andrapradesh, India. Plant growth promoting rhizobzcteria for sustainable agriculture. Proccedings of $2^{\text {nd }}$ Asian PGPR conference, Beijing, China. 21: 324-429.

Samanhudi, A. Y, Bambang, P. and Muji, R. 2014, Effect of organic manure and Arbuscular Micorrhizal Fungi on 
growth and yield of green ginger (Zingiber officinale Rosc.). $J$. Agric. Veterinary Sci., 1-5.

Ushamalini, C., Nakkeeran, P. and Marimuthu, T. 2008, Introduction of plant defence in turmeric plant by Trichoderma viridae. Archives of Phytopathol. Plant Protect., 41: 79-93.
Zarei, I., Mohammadi, G. Y., Sohrabi, D., Kahrizi, E., Khah, M. and Yari, K. 2011, Effect of different hydro priming times on the quantitative and qualitative characterstics of chickpea. African $J$. Biotechnol., 10: 14844-14850.

\section{How to cite this article:}

Soumya, S.M. Prashant, Sangeeta I. Macha, Vijay Kumar Kurnalliker, L.N. Yogeesh and Ravikumar, A. 2021. Seed Bio Priming for Enhancing Growth and Yield Attributes in Finger Millet Varieties (Eleusine coracana L. Garten.). Int.J.Curr.Microbiol.App.Sci. 10(01): 17881795. doi: https://doi.org/10.20546/ijcmas.2021.1001.209 